\title{
The assassination of Miguel Ángel Blanco: a key event that marked the turning point in press coverage of ETA violence
}

\author{
José María Caminos Marcet \\ University of the Basque Country \\ José Ignacio Armentia Vizuete \\ University of the Basque Country \\ Flora Marín Murillo \\ University of the Basque Country
}

\section{Key words}

Terrorism, ETA, press coverage, basque country, political assassination, Miguel Ángel Blanco

\begin{abstract}
In 1995, Euskadi ta Askatasuna, better known by its acronym ETA, changed its strategy in a way that would radically affect the media's coverage of the group's terrorist activities and eventually make Basque news organisations targets of their attacks. It was in that year that ETA ramped up pressure for the fulfilment of its political objectives by mounting a series of attacks that specifically targeted members of the Spanish judiciary and democratically elected officials primarily affiliated with the Popular Party and the Socialist Party, the two largest political parties in Spain. The apotheosis of this strategy was the July 12, 1997 assassination of Miguel Ángel Blanco, a councilman for the Basque city of Ermua affiliated with the PP, whom the group had abducted two days earlier. The brutal killing of Blanco marked a before and after in the media's coverage of ETA violence and constituted what authors such as Kepplinger and Habermeier (1995) refer to as a «key event». From that point on, the media would assume a more active role in the fight against ETA. This article explores how press coverage of fatal attacks perpetrated by ETA changed after the assassination of this municipal official by comparing reporting before and after the Blanco assassination and using framing theory to analyse the approaches applied by these four dailies to their coverage of ETA violence.
\end{abstract}




\section{El asesinato de Miguel Ángel Blanco como ejemplo de key event en el trata- miento mediático de los atentados mortales de ETA}

\section{Palabras clave}

Terrorismo, ETA, prensa, país vasco, atentados, Miguel Ángel Blanco

\section{Resumen}

A partir de 1995, ETA da un giro muy importante a su estrategia terrorista. Coloca a los medios de comunicación y a los periodistas en su punto de mira, inicia su presión mediante asesinatos al Poder Judicial y comienza una serie negra de atentados contra representantes de partidos políticos democráticamente elegidos, fundamentalmente del Partido Popular y del Partido Socialista. Este giro estratégico tiene su vértice culminante el 12 de julio de 1997, fecha en la que después de mantener secuestrado durante dos días al concejal del PP en Ermua Miguel Ángel Blanco, acaba por asesinarlo. La muerte del edil popular marca un antes y después en el tratamiento periodístico de los atentados de ETA, por lo que podría ser considerado un ejemplo de lo que autores como Kepplinger y Habermeier (1995) denominan key event. Desde esa fecha ya nada va seguir igual y los medios de comunicación adoptan una posición activa en la lucha contra ETA. Este texto analiza ese antes y después del tratamiento de los atentados mortales de ETA tras el asesinato del concejal del Partido Popular, tomando en consideración para ello las aportaciones realizadas desde la Teoría del Framing.

\section{Autores}

José María Caminos Marcet [josemaria.caminos@ehu.es] es catedrático de Periodismo de la Universidad del País Vasco.

José Ignacio Armentia Vizuete [ignacio.armentia@ehu.es] es catedrático de Periodismo de la Universidad del País Vasco.

Flora Marín Murillo [flora.marin@ehu.es] es profesora en la Universidad del País Vasco.

\section{Créditos}

This article is based on the findings of a research project funded by the Spanish Ministry of Science and Innovation. (Reference number CSO2010-19855). The authors are members of the Grupo Consoliddo en Investigación en Periodismo, a research group devoted to journalism funded by the Basque government. 


\section{Objectives and methodology}

In the late 1990s, ETA implemented a new strategy of threats and violence that specifically targeted judges, politicians and elected officials primarily affiliated with either the Popular Party (PP) or the Spanish Socialist Party (PSOE), Spain's two largest political parties.

The nature of this new strategy was made patently clear on July 12, 1997, when ETA assassinated Miguel Ángel Blanco, a city councilman in Emua affiliated with the PP.

The definitive shift in the type of individuals targeted by ETA during the period 1996-1998 can be clearly seen in the chronological list of victims contained in Table 1.

Table 1. Victims of ETA attacks perpetrated in 1996, 1997 and 1998

\begin{tabular}{|c|c|c|c|}
\hline YEAR & DATE & VICTIMS & PROFESSION \\
\hline \multirow{5}{*}{1996} & 06-02 & Fernando Múgica & $\begin{array}{l}\text { Lawyer, politician, and member of the Basque } \\
\text { socialist party (PSE-EE) }\end{array}$ \\
\hline & $14-02$ & Francisco Tomás y Valiente & $\begin{array}{l}\text { University professor and former president of } \\
\text { the Constitutional Court of Spain }\end{array}$ \\
\hline & 04-03 & Ramón Doral & Ertzaina (member of Basque police force) \\
\hline & $20-05$ & Miguel Angel Ayllón & Member of the Spanish Armed Forces \\
\hline & $26-07$ & Isidro Usabiaga & Businessman \\
\hline \multirow{13}{*}{1997} & 08-01 & Agustín Cuesta & Member of the Spanish Armed Forces \\
\hline & $30-01$ & Eugenio Olaciregui & Shop attendant \\
\hline & \multirow{2}{*}{$10-02$} & Rafael Martínez & Supreme Court Justice \\
\hline & & Domingo Puente & Barber at the Armilla Airforce Base \\
\hline & 11-02 & Francisco Arratibel & Businessman \\
\hline & \begin{tabular}{|l|l|}
$17-02$ \\
\end{tabular} & Modesto Rico & Member of the Policía Nacional \\
\hline & 11-03 & Javier Gómez Elósegui & Psychologist, Martutene Prison, San Sebastian \\
\hline & 24-04 & Luís Andrés Samperio & Member of the Policía Nacional \\
\hline & $03-05$ & José Manuel García & Member of the Guardia Civil \\
\hline & $12-07$ & MIGUEL A. BLANCO & City council for Ermua affiliated with the PP \\
\hline & 05-09 & Daniel Villar & Member of the Policía Nacional \\
\hline & $13-10$ & José M. Aguirre Larraona & Ertzaina (member of Basque police force) \\
\hline & 11-12 & José Luís Caso & City councilman affiliated with the PP \\
\hline \multirow{5}{*}{1998} & 09-01 & José A. Iruretagoyena & City councilman affiliated with the PP \\
\hline & $30-01$ & $\begin{array}{l}\text { Alberto Jiménez Becerril and } \\
\text { Ascensión García Ortiz }\end{array}$ & Politician affiliated with the PP and his wife \\
\hline & $06-05$ & Tomás Caballero Pastor & $\begin{array}{l}\text { City councilman affiliated with Unión del Pueblo } \\
\text { Navarro (UPN) }\end{array}$ \\
\hline & 08-05 & Alfonso Parada & Member of the Guardia Civil \\
\hline & $25-06$ & Manuel Zamarreño & City councilman affiliated with the PP \\
\hline
\end{tabular}


The purpose of this study was to compare and analyse press coverage of fatal attacks perpetrated by ETA before and after the abduction and murder of Miguel Ángel Blanco. It covers press reporting on the $13^{1}$ assassinations perpetrated by ETA in 1996 and 1997 prior to the group's execution of Miguel Ángel Blanco as well as coverage of the eight assassinations that followed this event, three of which occurred in 1997, and five of which took place in 1998.

A comparative study of reporting during these two periods was carried out to ascertain whether the assassination of Blanco was, in fact, a key event that marked a change in the way the press reported on ETA violence as claimed by Arcadi Espada (2002), who has asserted, «Until the death of Miguel Ángel Blanco-that marked a before and after-terrorism and its victims had been minimized and the assassins had been directly or indirectly mythologized. I'm not inventing in the least when I make this assertion. It's based on an analysis of the newspapers of the period $»^{2}$.

Authors such as Idoyaga and Ramírez de la Piscina (2000, 273) have pointed out the active role played by the media in the fight against terrorism from 1998 (the last year analysed for this study) through 2000, observing that «Cayetano González Hermosilla, Director of Communication for the Spanish Interior Ministry [during this period] has recently spoken of the 'maturity' demonstrated by the press throughout the country concerning the 'terrorist problem', emphasizing the need for journalists to reject false notions of neutrality when addressing such issues» ${ }^{3}$.

Margarita Robles, a member of the General Council of the Judiciary, has also spoken of the media's contribution to the fight against terrorism following the death of Blanco, noting, "It's precisely because of the media's importance that all politicians in every country throughout the world have always had a keen interest in controlling the media or maintaining excellent relations with them» ${ }^{4}$ (VV.AA.: 2000, 27).

The two main objectives of our comparative analysis of Basque press coverage of ETA violence before and after the Blanco assassination were to verify whether this event supposed a point of inflection in the press's ongoing coverage of

1 As previously noted, for the purposes of this study, the two ETA attacks perpetrated simultaneously on February 10 , 1997 have been categorized as one event.

2 «Hasta la muerte de Miguel Ángel Blanco, por poner una huella en el camino, el terrorismo y sus víctimas han sido minimizados, y los asesinos, mitificados por activa y por pasiva. Y no me invento nada al afirmar tal cosa. Esto es la derivación de un análisis de los periódicos de la época».

3 «Cayetano González Hermosilla, responsable de comunicación del Ministerio del Interior ha resaltado recientemente la "madurez" demostrada por los medios de comunicación de todo el Estado a la hora de abordar el denominado "problema del terrorismo" al tiempo que subrayaba la necesidad de desterrar la idea de la neutralidad periodística a la hora de abordar estos temas».

4 «Y es por eso, por esa importancia que tienen los medios de comunicación, que todos los poderes políticos en todos los países y en todos los momentos han tenido un especial interés bien en controlar los medios de comunicación o bien en tener unas magníficas relaciones con ellos». 
ETA violence and to determine whether Blanco's death was a key event that influenced textual and photographic coverage of subsequent ETA assassinations.

A study carried out by Elba Díaz Cerveró on Le Monde's coverage of ETA assassinations from 1968 onward notes that «coverage, which before had been modest, was broadly expanded after the assassination of Miguel Ángel Blanco» ${ }^{5}$ (2012: 195).

The possibility that the assassination of Blanco could be considered a key event for the Basque press ran parallel to the assertion made by Kepplinger and Habermeier (1995) that «key events change the criteria for the selection of news and stimulate new activities which in turn get covered by the media» (1995: $371)$.

News coverage analysed for this study was drawn from the archives of four major newspapers: El Correo Español, Deia, Egin and El País. The first three are Basque newspapers and the fourth has the highest daily national circulation of any newspaper in Spain and has produced a Basque edition edited in Bilbao since 1997. These dailies were chosen because they represent a broad spectrum of political opinion: El Correo Español is known for its centre-right positions, El País covers news from a centre-left point of view, and Deia and Egin reflect the opinions of moderate and leftist Basque nationalists respectively. Because it is owned by the same group that publishes El Correo Español, which enjoyed a wider circulation during the period in question and also ran a Basque edition, El Dario Vasco, which has a large following in Gipuzkoa, was not included in the sample analysed.

Table 2 compares the circulation and readership of the newspapers analysed for this study.

Table 2. Circulation and readership of newspapers analysed (1997)

\begin{tabular}{|l|c|c|}
\hline Diario & Circulation 1997 & Readership 1997 \\
\hline El Correo & 133,014 & 576,000 \\
\hline Egin & 52,311 & 109,000 \\
\hline Deia & $48,313^{*}$ & 85,000 \\
\hline El País & 440,628 & $1,463,000$ \\
\hline
\end{tabular}

*The circulation figure for Deia given here corresponds to 1990. The OJD database has no circulation data for Deia for the year 1997 due to that daily's withdrawal from the OJD verification program from 1991 to 2007.

Source: OJD and AIMC

5 «Las informaciones - que de forma general no habían superado el breve hasta entonces-, aumentaron considerablemente en tamaño a partir del asesinato de Miguel Ángel Blanco». 
The sample contained visual and textual content from both the front pages and interior sections of these four papers. A method developed by Piñuel and Gaitan (1995: 519), described by García Galera and Ruíz San Roman (1999: 47) as a «systematic method for producing objective quantitative results» ${ }^{6}$, was used to quantitatively measure the material gathered.

How each newspaper framed its coverage was also analysed, in line with Entmann's (1993: 52) definition of framing as the process of rendering given aspects of a perceived reality more salient and therefore more relevant than others in a text used in communication.

Mainstream industry criteria for prioritising and measuring news content such as the size and placement of front-page and interior section articles and the inclusion of photographs and infographics were studied as framing devices. As Pilar Giménz Armentia has noted, «sections, editorial pieces, an article’s length and the page it appears on, layout, sources, headlines and photographs are all elements newspapers use to construct and frame news» $\gg^{7}$ (2006: 57).

One can get a basic idea of the degree of importance the press accorded to ETA assassinations by studying the number of pages, news articles, photographs and infographics newspapers devoted to the coverage of these events.

Some of our findings concerning the presence and relative placement of photographs and infographics coincide with those reported by Nekane Parejo in Representación gráfica de los atentados de ETA (1968-1997), which served as a reference work, and also confirm various points of framing theories, which as Miguel Vicente Mariño and Pablo López Rabadán have observed, «link journalistic processes with communicative interaction and the social construction of reality ${ }^{8}$ (2009: 21).

Images, like textual content, can be framed to express particular points of view. As Esparza and Parejo explained, «an image is the most effective communication support for the two poles of terrorist activity, given that the pursued objectives are emotional in character (2012: 131)». Selecting some photos rather than others to flesh out a story is what photo editors do. José Igartua et al. (2007: 94) cite Entman (1991, 1993) and Tankard (2001) in defending the application of framing theory to image analysis, arguing that «the images used to illustrate textual information always contain certain elements, which if read contextually, reveal the journalistic approach applied to a given story or how that particular news has been handled ${ }^{9} »$. Messaris and Abraham indicated that «the use of

6 «Nos acerca de una forma sistemática, objetiva y cuantitativa a unos resultados».

7 «Las mismas secciones de los periódicos, los editoriales, la extensión, la página donde se ubique, el diseño, las fuentes de información, los titulares, las fotografías, son todos ellos formas que tienen los periódicos de enmarcar y encuadrar las informaciones».

8 «La interacción comunicativa y la construcción social de la realidad»

9 «En las imágenes que acompañan a la información textual están presentes ciertos elementos que, a través de su relación, hacen patentes diferentes enfoques o tratamientos de la información». 
photographic media (including television and video) in the framing process could diminsh the likelihood that viewerv would question what they see (2001: 217)».

Images to be analysed were divided thematically into the following categories: crime scene, property damages, friends and family members of the victims, context photos, terrorists and public demonstrations.

To analyse how they had been framed, news story headlines were divided into the following categories: victims, friends and colleagues, family members, politicians, civil society organizations, members of the security forces, political institutions, movements, ETA, public protests against terrorism, editorial writing, labour unions, religious institutions, and public figures. Previous research by J. Manuel Sánchez-Duarte and Víctor Sampedro documented in "Visibilidad mediática y terrorismo: El caso de las víctimas de ETA (2011: 183-210)” served as a reference during this process.

As the presence or absence of editorial articles is a clear indicator of the degree of importance newspapers confer on a given event or topic, editorial pieces were also tracked and analysed.

\section{Analysis of the sample}

\subsection{El Correo}

\subsubsection{Analysis of front-page news coverage}

El Correo published a front-page article after every ETA assassination covered by this study. An analysis of its reporting of the 13 fatal attacks carried out prior to the Blanco assassination reveals that it ran five-column front-page stories for $30.8 \%$ of these events and four-column front-page stories for the other $69.2 \%$. However, it allotted significantly more front-page space to assassinations committed after the Blanco murder: five-column stories for $62.5 \%$ and fourcolumn stories for the other $37.5 \%$.

El Correo used photos in its front-page coverage of every assassination perpetrated by ETA after the death of Miguel Ángel Blanco, although it had only included them in its front-page coverage of $92.3 \%$ of prior ETA assassinations.

Most of the images used by El Correo in its front-page coverage of assassinations carried out before the death of Blanco depicted either property damage or the victims, although the daily also ran images of the victims' family and friends and context images of the crime scene. The newspaper continued to run images of property damage in its reporting on fatal attacks perpetrated after the Blanco assassination, but it stopped running context images and also published more photos of the victims and other images that tended to put a human face on the tragedy. 
Figure 1. Types of photographs used in front-page reporting (El Correo)

-Before " After

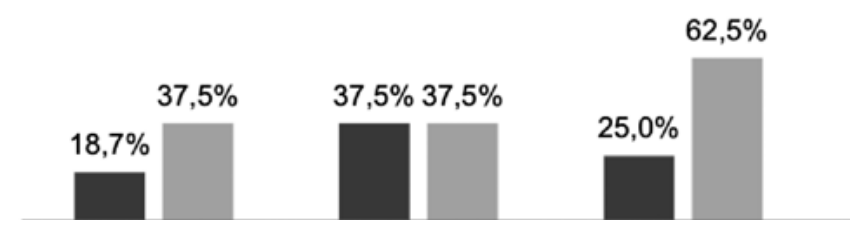

\subsubsection{Analysis of news articles}

An analysis of news articles related to ETA assassinations published by El Correo reveals that the murder of Miguel Ángel Blanco marked an editorial tipping point for this daily. It devoted a total of 87 pages to the eight assassinations carried out after the death of Blanco compared to the 65 pages it devoted to all the assassinations perpetrated by the terrorist organisation during 1996 and 1997. In the wake of this attack, it effectively doubled the space it reserved for coverage of this type of event.

Figure 2. Number of pages containing related news and number of articles ( $E l$ Correo)

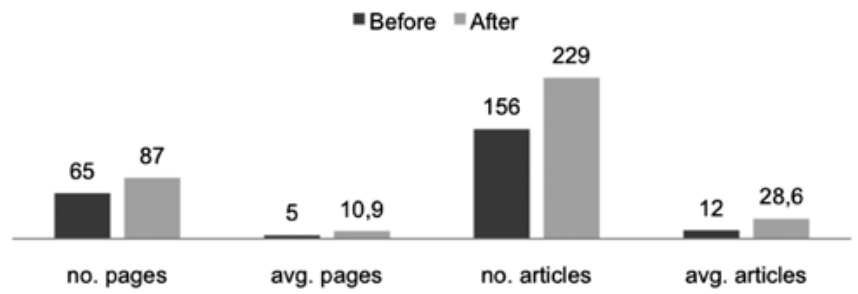

An analysis of the headlines of articles published in the interior sections of $E l$ Correo revealed three major shifts in focus:

a) Although ETA victims, their friends and their families were mentioned in $21.8 \%$ of the related interior section headlines published by El Correo prior to the Blanco murder, they appeared in only $13.8 \%$ of related interior section headlines published after that event.

b) Political figures, government institutions and public protests were all mentioned more frequently in the headlines of related interior section articles published after the assassination of Blanco, rising from $14.7 \%$ to $26.2 \%$ of the total in the case of political figures, $8.3 \%$ to $11.8 \%$ in the case of government institutions, and $1.9 \%$ to $9.6 \%$ in the case of public protests. 
c) Statements by well-known athletes, celebrities, etc. condemning ETA violence appeared in $11.8 \%$ of the ETA-related interior section headlines published after the death of Blanco.

Before the Blanco assassination, El Correo ran a total of 78 photographs (an average of 6 per event) in its interior section reporting on ETA violence. However, the newspaper published many more photographs in its coverage of assassinations perpetrated after this event: 140 in all, or an average of 17.5 per event.

As the total number of photographs published increased, their content and focus changed considerably. After the death of Blanco, the daily ran fewer images of property damages and the percentages of photographs depicting victims fell from $16.7 \%$ to $7.9 \%$. Images portraying terrorists, which had supposed $6.4 \%$ of all images published on ETA violence prior to the Blanco assassination, were not used in reporting after that event.

After the Blanco assassination, the newspaper ran a slightly higher proportion of photographs that drove home the human cost of ETA violence (images depicting family members, friends, neighbours, etc.) and significantly more photographs of public protests.

Figure 3. Types of photographs appearing in interior sections (El Correo)

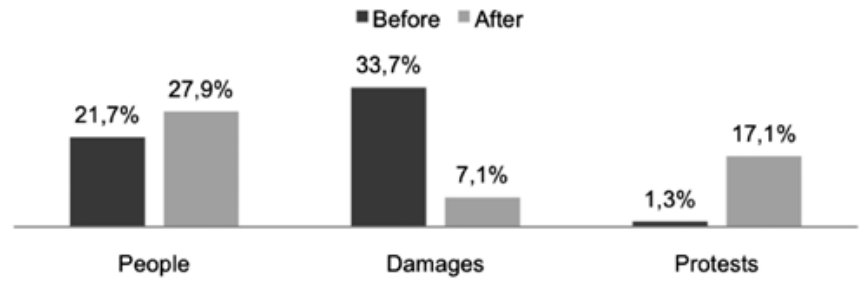

El Correo included infographics in its coverage of $84.6 \%$ of the fatal attacks perpetrated by ETA prior to the death of Blanco. After this event, its reporting on ETA assassinations always featured infographics.

\subsubsection{Analysis of editorial articles and opinion columns}

El Correo ran an editorial piece in response to $84.6 \%$ of the assassinations perpetrated by ETA during the year and a half leading up to the Blanco assassination and opinion columns related to $23.1 \%$ of these events. However, these columns were never given a cover line on the front page. An editorial article was published in response to every fatal attack that occurred after the Blanco murder and related opinion columns were published after $62.5 \%$ of these events.

Figure 4. Editorials and opinion columns devoted to ETA assassinations (El Correo) 


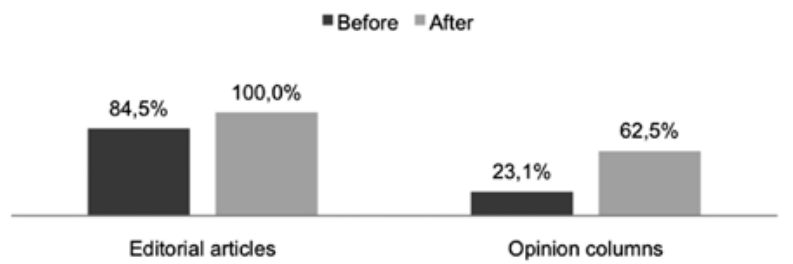

El Correo ran more editorial articles and opinion columns on ETA violence after the murder of Miguel Ángel Blanco.

\subsubsection{Observations on El Correo's coverage of ETA assassinations}

- El Correo ran front-page stories after every ETA assassination that occurred during the period analysed for this study. However, it devoted more front-page articles to assassinations perpetrated after the death of Blanco.

- El Correo ramped up its coverage of ETA violence after the death of Blanco. It devoted twice the number of pages to reporting on ETA assassinations perpetrated during the remaining three months of 1997 and 1998 than it had to assassinations carried out during 1996 and the first five months of 1997.

- This daily also made reference to statements against ETA violence made by prominent athletes, cultural figures and other celebrities in $11.8 \%$ of the headlines of related articles published after the death of Blanco.

- El Correo published an editorial piece in response to every ETA assassination perpetrated after the Blanco murder and ran nearly three times as many opinion columns and other opinion articles in response to these events.

- The type of photographs El Correo used in its reporting on ETA violence also changed after Blanco's death: whereas on previous occasions the daily tended to run mainly photographs of property damages on the front page, after that event it published more images that conveyed the human cost of ETA terrorism. El Correo used almost three times more photographs to flesh out interior section stories related to attacks perpetrated after the Blanco murder. It also ran fewer images of property damages and victims and more images of people and public protest marches against ETA violence.

\subsection{Deia}

\subsubsection{Analysis of front-page news coverage}

Deia ran a front-page story in response to every fatal attack ETA carried out during the period studied, but reporting on assassinations carried out after the murder of Miguel Ángel Blanco was given a higher level of visibility. Articles related to $76.9 \%$ of the assassinations carried out prior to this event were placed well above the centre fold, $15,5 \%$ of such events were given coverage 
further down the page and $7,7 \%$ received coverage below the fold. After the murder of Blanco, all subsequent ETA assassinations were treated as top news stories.

Deia ran five-column front-page stories related to $30.8 \%$ of the assassinations perpetrated by ETA prior to the death of Blanco, four-column stories for $46.1 \%$, and two-column stories for the remaining $23.1 \%$. The stories it ran about assassinations committed after the death of Blanco tended to be, on the average, longer: it published five-column front-page stories related to $12.5 \%$ of these assassinations and four-column articles related to $87.5 \%$.

Graphics were featured in front-page reporting on $84.6 \%$ of the attacks carried out by ETA during the year and a half leading up to the murder of Miguel Ángel Blanco. This percentage dropped to $62.5 \%$ after the councilman's death.

The type of images Deia published on its front page also changed after the Blanco assassination: in its front-page reporting on subsequent assassinations, it ran more photographs of victims and their friends and family, fewer images documenting property damages and no context images. Deia did not run frontpage photographs of public protests during either period studied.

Figure 5. Types of photographs appearing on the front page (Deia)

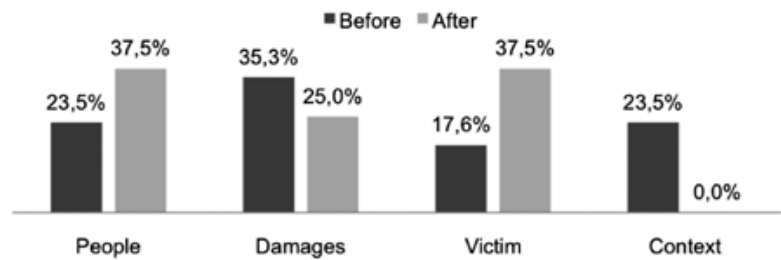

\subsubsection{Analysis of news articles}

Deia ran 60 pages containing a total of 190 news stories related to the 8 assassinations ETA carried out between the death of Blanco and the end of 1998 compared to the 47 pages (156 articles) it had published related to assassinations perpetrated during the prior period, an increase of $108 \%$.

Figure 6. Number of pages containing related news and number of articles (Deia)

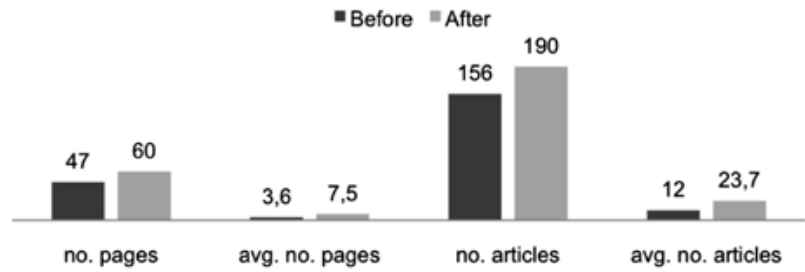


An analysis of the headlines of articles on ETA violence published by Deía revealed the following:

a) The victims' families were mentioned in $5.8 \%$ of the headlines of related articles published after the death of Blanco compared to $1.3 \%$ of the headlines during the prior period. Other topics that received more coverage in headlines after this event included political figures (42\% compared to a previous $37.8 \%$ ), government institutions (12.6\% compared to $8.3 \%)$ and public protests $(11.6 \%$ compared to $1.9 \%)$.

b) Friends and colleagues of the victims were mentioned in $2.6 \%$ of related article headlines published after the Blanco murder compared to $5.1 \%$ during the first period studied. Civil society organisations were mentioned far less frequently after the Blanco murder, appearing in $2.6 \%$ compared to an earlier $11.5 \%$.

Deia used a total of 143 photographs in its coverage of the 8 ETA assassinations perpetrated after the death of Blanco (17.9 per event) compared the 80 photographs (6.1 per event) that it had featured in reporting on prior assassinations. Whereas the daily had published mainly photos that documented property damages and provided context in its reporting on earlier attacks, after the death of Blanco, it ran more context photos and images that put a human face on the events, fewer images documenting property damages and started including photos of public protests in its coverage.

Figure 7. Types of photographs appearing in interior sections (Deia)

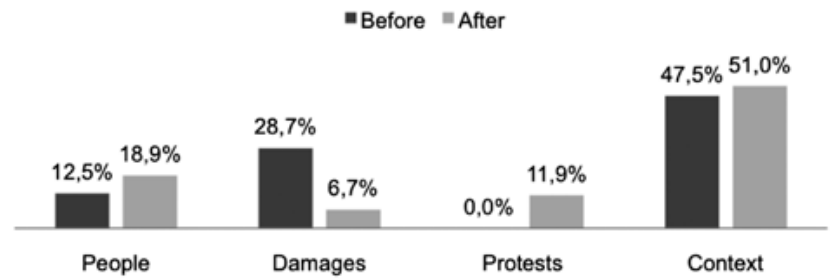

The use of infographics increased only slightly during the second period studied. They were used in reporting related to $37.5 \%$ of the assassinations committed during the second period compared to $30,8 \%$ committed during the first period.

\subsubsection{Analysis of editorial articles and opinion columns}

After the death of Blanco, Deia ran more editorial articles related to ETA violence, although it did not publish one after every subsequent assassination. Curiously, it ran fewer related opinion columns after the Blanco murder.

Figure 8. Editorials and opinion columns devoted to ETA assassinations (Deia) 


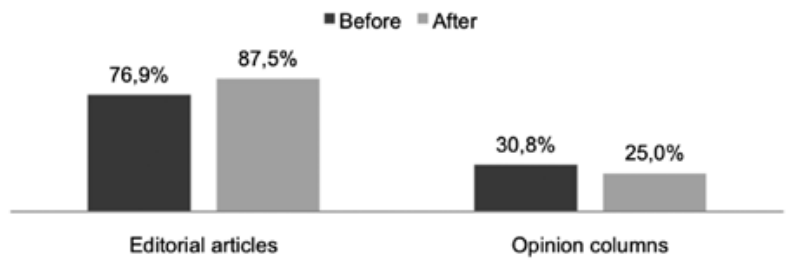

Deia ran more editorial articles and fewer opinion columns related to ETA violence after the death of Miguel Ángel Blanco.

2.2.4. Observations on Deia's coverage of ETA assassinations

- Deia treated every ETA assassination covered by this study as front-page news. However, after the death of Miguel Ángel Blanco, it expanded its coverage, running four-column articles in response to $87.5 \%$ of subsequent ETA assassinations.

- The average number of pages Deia devoted to the coverage of ETA assassinations doubled, rising from 3.6 before the death of Blanco to 7.5 for subsequent incidents.

- Family members, politicians, government institutions and public protests were more frequently mentioned in the headlines of articles published about ETA violence after Blanco's death.

- After the murder of Blanco, Deia ran more editorial articles in response to incidents of ETA violence, although it did not publish an editorial article for every subsequent assassination and ran slightly fewer related opinion columns and other opinion pieces after this event.

- Deia ran more images of victims and other people in its front-page coverage of ETA assassinations carried out after the death of Miguel Ángel Blanco. It also ran almost three times more photographs per event in its interior sections, far fewer images of property damages and a greater number of photographs documenting public.

\subsection{Egin}

\subsubsection{Analysis of front-page news coverage}

Although Egin treated every ETA assassination covered by this study as frontpage news, the placement of these stories varied: it ran stories related to $76.9 \%$ of the assassinations committed prior to the death of Blanco well above the fold, articles related to $15.5 \%$ further down the page and articles related to $7.7 \%$ below the centre fold. Placement improved after the death of Blanco: front-page stories related to $87.5 \%$ of these assassinations were placed well above the 
centre fold and stories related to the other $12.5 \%$ were published slightly lower on the front page but still above the centre fold.

The difference between of the size of related articles published before and after the death of Blanco is even more dramatic. Whereas Egin ran four-column articles in response to $46.1 \%$ of the assassinations leading up to the death of Blanco, two-column articles for another $15.4 \%$ and one-column articles for the final $15.4 \%$, its front-page articles related to ETA violence following the murder of Blanco were substantially longer: $71.4 \%$ of the events were allotted fivecolumn stories, $14.3 \%$ received four-column stories and another $14.3 \%$ were given three-column stories.

As front-page articles became longer, fewer photographs were used to illustrate them. Whereas photographs had appeared in front-page coverage of $91.6 \%$ of the assassinations perpetrated during the first period studied, they only appeared in front-page coverage of $83.7 \%$ of the assassinations committed during the second period.

During the second period, Egin ran fewer front-page photographs of property damages and more images that portrayed victims, contextualised the event or contained human elements. It did not run front-page photographs of public protests during either period.

Figure 9. Types of photographs appearing on the front page (Egin)

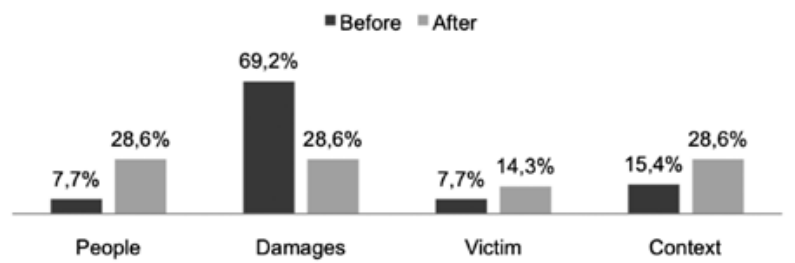

\subsubsection{Analysis of news articles}

Egin devoted a total of 39 pages to coverage of assassinations perpetrated prior to the death of Blanco, an average of three per event. During this period, it published 75 news stories, an average of 5.8 for each assassination. While the number of articles it published in response to each of the eight assassinations (58) that occurred after the death of Blanco was a bit higher compared to the first period (a average of 7.2 per event), the number of pages devoted to news related to ETA assassinations carried out during both periods was the same (an average of 2.9 per event).

Figure 10. Number of pages containing related news and number of articles (Egin) 


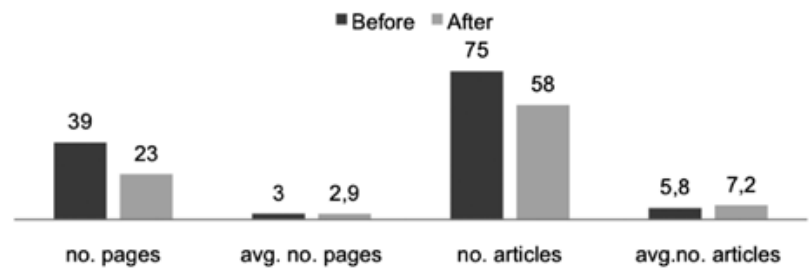

Regarding the headlines of news articles on ETA violence published by Egin during the period studied, it was observed that:

a) Prior to the Blanco assassination, $30.7 \%$ of the headlines of articles published by Egin on ETA violence highlighted political figures, $13.3 \%$ mentioned government institutions and $17.3 \%$ were devoted to descriptions of the attacks. The percentages for each category declined slightly in the daily's reporting of ETA assassinations committed after the Blanco murder, although they remained proportionally similar.

b) References to victims, which figured in $8 \%$ of the headlines of articles published during the first period studied, were only present in $3.4 \%$ of the headlines of related articles published after the Blanco murder, and references to the victims' families and friends, which had appeared in $1.3 \%$ of the headlines of articles published during the first period, did not appear in any of the headlines published during the second period.

c) After the Blanco assassination, the headlines of articles published by Egin began to mention public protests against ETA violence (which appeared in $5.2 \%$ ) and criticism of Herri Batasuna ${ }^{10}$ (which appeared in $6.9 \%$ ), neither of which had been mentioned in the headlines of related articles published prior to this event.

Egin included a total of 51 photos in its reporting of assassinations perpetrated by ETA during the first period studied (an average of 3.9 per event). In its reporting of fatal terrorist attacks carried out after the death of Blanco, it ran a total of 33 photos (an average of 4.1 per event).

The types of photographs published varied from one period to another. Egin ran context photographs to flesh out its reporting on $54.9 \%$ of the assassinations carried out during the first period, images of property in its coverage of $23.5 \%$ of these attacks and photos of the victims in its coverage of $11.8 \%$. It used images depicting the human side of only $5.9 \%$ of these tragedies and images documenting public protests in coverage of $3.9 \%$. The mix used in reporting on attacks carried out after the murder of Blanco was substantially different.

10 Herri Batasuna was a coalition of left-wing Basque political movements founded in April 1978 and restructured in 2001 under the name Batasuna. It was banned as a political party by the Spanish Supreme Court in application of Organic Law 6/2002 of 27 June on political parties. The court based its ruling in this case on what it considered to be evidence that Batasuna functioned as a part of ETA's political strategy. 
During this period, context photographs only appeared in reporting on $42.4 \%$ of the events and images of property damage were featured in reporting related to $18.2 \%$. Egin ran slightly more photographs of victims after the death of Blanco; they appeared in reporting on $12.1 \%$ of the events during this period.

During the second period, Egin ran more photographs containing humanising elements: reporting on $15.1 \%$ of the attacks perpetrated after the murder of Blanco featured such photographs compared to $12.1 \%$ during the first period studied.

Figure 11. Types of photographs appearing in interior sections (Egin)

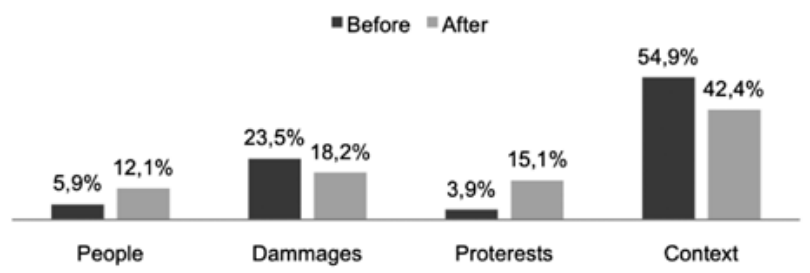

\subsubsection{Analysis of editorial articles and opinion columns}

Egin ran more editorial articles related to ETA attacks following the death of Miguel Ángel Blanco, but stopped publishing related opinion columns.

Figure 12. Editorials and opinion columns devoted to ETA assassinations (Egin)

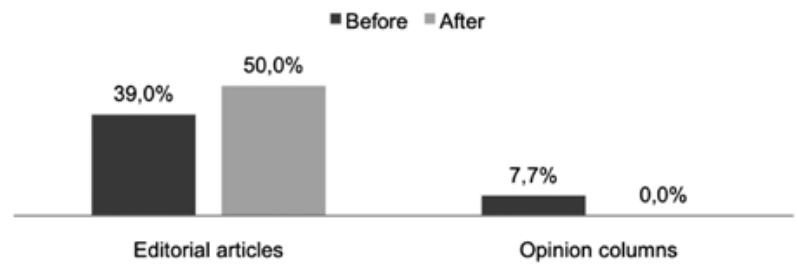

\subsubsection{Observations on Egin's coverage of ETA assassinations}

- Egin ran front-page stories related to all the assassinations covered by this study, but it allotted more space to coverage of those carried out after the death of Blanco. After this event, the number of five-column articles related to ETA violence increased, and the daily no longer limited its coverage of assassinations to one or two columns.

- The number of pages devoted to the coverage of assassinations remained stable throughout the entire period studied: an average of 3 pages per event.

- Both before and after the death of Blanco, the greater percentage of the headlines for Egin's news stories about ETA violence contained references to 
political figures and government institutions. References to friends and family members of victims were curiously absent during the second period studied, although headlines for related articles published after the Blanco murder were more critical of Herri Batasuna.

- After the murder of Blanco, Egin ran 50\% more editorial articles related to ETA assassinations, although it stopped featuring opinion columns and pieces on this topic.

- Until the Blanco assassination, the photographs used by Egin in its frontpage reporting on ETA attacks almost always documented property damages. After Blanco's death, however, the daily began to run more images that explored the human angles of these incidents on the front page. It also ran more photographs of people and fewer context photos and images of property damages in interior sections.

\subsection{El País}

\subsubsection{Analysis of front-page news coverage}

Although El Pais treated all ETA assassinations perpetrated during the period analysed as front-page news, every assassination committed after the death of Blanco was treated as the day's top news story. The paper ran five-column articles for $50 \%$ of the assassinations perpetrated during the second period studied, four-column-articles for $37.5 \%$ and three-column articles for the remaining $12.5 \%$

Front-page reporting on assassinations committed prior to the death of Blanco always included photographs: $77.7 \%$ of these images documented property damages and $11.1 \%$ depicted the victims, their friends and their families.

El País ran photographs in its front-page coverage of only $71.4 \%$ of the assassinations committed by ETA after the Blanco murder. Of the images used during this period, $33.3 \%$ documented property damages, another $33.3 \%$ added a human perspective, $22.2 \%$ depicted the victims and $11.1 \%$ documented public protests.

Figure 13. Types of photographs appearing on the front page (El País)

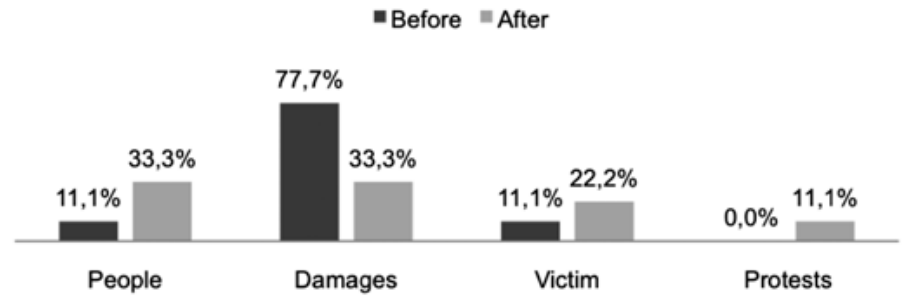




\subsubsection{Analysis of news articles}

El País increased its coverage of ETA assassinations after the murder of Miguel Ángel Blanco by $71.4 \%$, devoting almost twice as many pages to this topic after this event than it had before. It ran a total of 43 pages and 124 news items (an average of 5.3 pages and 15.5 articles per event) to the 8 assassinations perpetrated after the death of Blanco compared to 41 pages and 102 news items (an average of 3.1 pages and 7.8 articles) related to assassinations carried out prior to Blanco's death.

Figure 14. Number of pages containing related news and number of articles (El País)

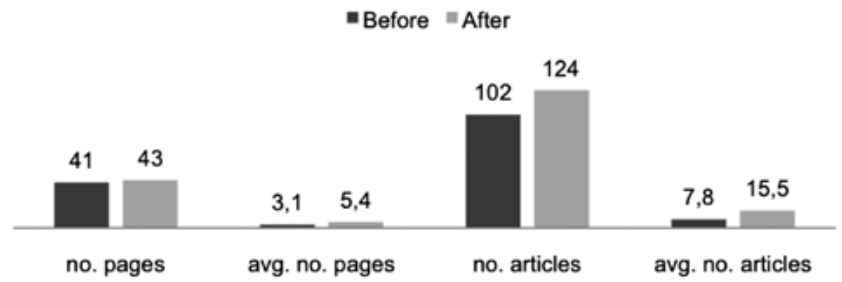

Content analysis of the headlines of articles published by El País related to assassinations carried out by ETA revealed that:

a) Prior to the Blanco assassination, $13.8 \%$ of the headlines of articles related to ETA violence published by El País contained references to the victims or statements made by family members, friends or other individuals. This percentage dipped slightly to $12.8 \%$ after the death of Blanco.

b) References to political parties, which appeared in $34.3 \%$ of the headlines of related articles published prior to the death of Blanco, became more frequent after this event, figuring in $42.8 \%$ of the headlines during the second period studied.

c) In contrast to the other newspapers analysed, El País mentioned ETA commando units in the headlines of the articles it published on ETA violence. Such references appeared in the headlines of $11.8 \%$ of the related stories published prior to the death of Blanco and the headlines of $9.7 \%$ of the related stories from September 1997 through June 1998. This daily also made critical references to organisations such as Herri Batasuna in the headlines of its articles on ETA violence: such references appeared in the headlines of $2.9 \%$ of the related stories published prior to the Blanco murder and 5.6\% published after that event.

d) Prior to the Blanco assassination, El País mentioned public protests in the headlines of $3.9 \%$ of the stories it published related to ETA violence. Due, in part, to an increase in the number of public demonstrations organised after Blanco's murder, this percentage rose to $8.9 \%$ during the second period studied. 
El País used 39 photographs in its reporting on ETA assassinations carried out prior to the murder of Blanco, an average of 3 per event, compared to 45 photographs during the second period of reprorting, an average of 5.6 per event.

Prior to the Blanco assassination, the lion's share of related photographs published by El País documented property damages (used in the coverage of $41 \%$ of the attacks carried out during this period), followed by context images $(25.6 \%)$, images that added a human perspective $(17.9 \%)$ and a much smaller number of photographs of ETA militants involved in the attacks $(2.6 \%)$.

An analysis of images published after Blanco's death reveals an evolution in the daily's visual coverage of ETA violence: although the proportion of context photographs remained fairly steady (included in reporting related to $31.1 \%$ of the following assassinations), the paper ran many more photographs of family members and friends of the victims (featured in reporting on $31.1 \%$ of these assassinations), fewer images of the victims (used in the coverage of $11.1 \%$ ) and refrained from publishing images of ETA militants involved in the attacks. Photographs documenting public protests were used in the coverage of $15.6 \%$ of the assassinations perpetrated after the death of Blanco.

Figure 15. Types of photographs appearing in interior sections (EL País)

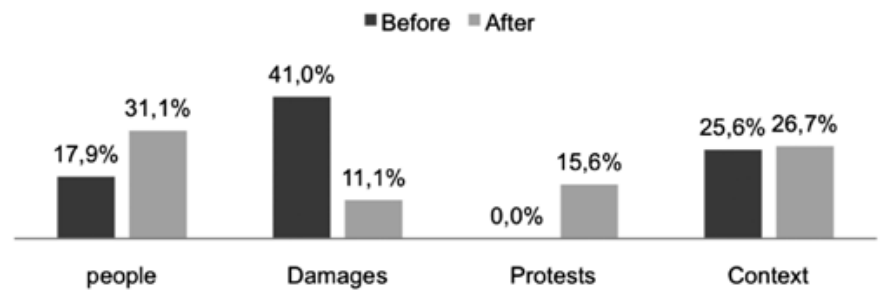

El País also used more infographics in its coverage of assassinations perpetrated after Blanco's death: they appeared in reporting on $75 \%$ of the subsequent assassinations compared to $61.5 \%$ of the attacks carried out during the prior period.

\subsubsection{Analysis of editorial articles and opinion columns}

El País ran more editorial articles after the death of Blanco. It published editorial articles in response to all 8 of the assassinations carried out after Blanco's murder compared to only $69 \%$ of the assassinations committed during the first period studied.

The daily also ran more opinion articles and columns on ETA violence after the Blanco assassination, publishing them after $62.5 \%$ of the assassinations carried out during the second period studied compared to $23.1 \%$ of the assassinations committed during the first period. 
Figure 16. Editorials and opinion columns devoted to ETA assassinations (El País)

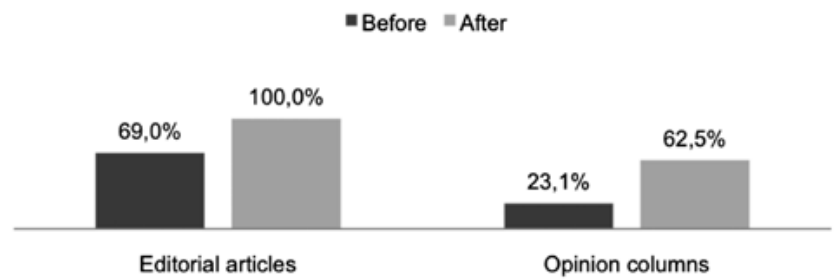

Findings show that El País ran significantly more editorial articles on ETA violence and related third-party opinion pieces after the death of Miguel Ángel Blanco.

\subsubsection{Observations on El Pais's coverage of ETA assassinations}

- El País ran a front-page story on all the assassinations ETA carried out after the murder of Miguel Ángel Blanco, a clear shift from its prior policy. It also ran more related five-column stories during this period.

- The number of pages El País devoted to the coverage of ETA violence almost doubled after the Blanco assassination, rising from an average of 3.1 pages to 5.4 pages per attack.

- The headlines of articles on ETA violence published after the Blanco assassination mentioned political parties, government institutions and public protests more frequently than those published during the first period studied and were occasionally critical of Herri Batasuna, whereas the number of references made in headlines to victims and statements made by their friends and family members remained stable throughout both periods studied.

- The paper published an editorial article in response to every assassination that ETA carried out after the death of Blanco and published almost three times the number of opinion columns and articles that it had prior to that event.

- El País used fewer photographs documenting property damages and more photographs depicting friends and relations of the victims and public protests in its front-page coverage of assassinations perpetrated after the death of Blanco. The mix of images used in interior sections also changed: although the proportion of context images remained roughly the same, the paper ran fewer photographs of property damages and more that conveyed a human perspective or documented public protests.

\section{General conclusions}

1.- The Basque press handled news related to ETA assassinations differently after the death of Miguel Ángel Blanco. This study has allowed us to clearly 
establish, as writers such as Arcadi Espada have claimed, that the murder of Blanco marked a turning point in press coverage of ETA violence.

Furthermore, an analysis of the ways in which the dailies included in this study reframed their coverage of assassinations perpetrated after the death of Blanco, leads us to conclude that it was a «key event» in the evolution of reporting on ETA violence.

2.- It should be noted that 5 of the 8 individuals assassinated during the period in which the press's approach to covering ETA violence changed substantially were politicians affiliated with the conservative Popular Party, a fact that made these events more newsworthy from a journalistic point of view.

3.- Although all four newspapers analysed for this study ran front-page news stories about the assassinations perpetrated by ETA between February 1996 and June 1998, they allocated more front-page space to reporting on assassinations carried out after the death of Blanco and placed a greater emphasis on the victims.

4.- All the newspapers studied except Egin expanded their reporting on ETA violence after the Blanco murder. El Correo, Deia and El País allotted almost twice the number of pages to reporting on assassinations carried out after his death. Only Egin maintained the same level of coverage during both periods (an average of 3 per assassination).

5.- The headlines of articles on ETA violence published by all four newspapers after the Blanco murder frequently mentioned political parties, government institutions and public protests. It was striking, however, that those run by El Correo, Deia and Egin during this period contained fewer references to the victims, their friends and their families. The headlines of articles related to assassinations published by El Correo following the death of Blanco were occasionally critical of Herri Batasuna and $11.8 \%$ called attention to statements made by well-known athletes, celebrities and other public figures condemning ETA violence. El País was the only newspaper included in this study to directly refer to ETA commando units in story headlines; such references appeared in the headlines of $11.8 \%$ related news articles published prior to the Blanco assassination and $9.7 \%$ of those published afterwards.

6.- El Correo and El País ran editorial articles in response to every assassination ETA carried out after the death of Miguel Ángel Blanco. Deia also ran more editorial pieces during this period, but did not publish one for every subsequent event, and Egin, which was the daily least given to publishing this type of article regarding ETA violence, ran them in response to only $50 \%$ of these events. El Correo and El País ran almost three times as many related opinion articles and columns after the death Blanco. On the other hand, Deia ran slightly fewer during this period, and Egin, which had published them after $7.7 \%$ of the assassinations that took place during the first period studied, ran none in response to the assassinations perpetrated after the death of Blanco. 
7.- All the dailies analysed except El Correo used fewer photographs in their front-page coverage of ETA assassinations committed after the death of Blanco, and all ran a substantially different mix of photographs in their coverage during the second period studied. Prior to the Blanco murder, all four published primarily images of property damage, but after that event, El Correo, Deia and El País began to include photographs that explored the human cost of ETA terrorism and documented public protests against ETA violence on their front pages. Egin ran more photographs conveying the human side of these tragedies on its front page after the Blanco murder, but never images of public protests.

8.- After the Blanco murder, these dailies - again, with the exception of Egin - ran a significantly higher number of photographs in related stories placed in their interior sections. El Correo and Deia ran almost three times as many photographs in their interior section reporting on subsequent ETA assassinations, and El País almost doubled the number it used in its interior section reporting on the same events. In terms of the types of photographs used by these dailies in their interior section reporting of subsequent assassinations, all took a similar approach: they ran fewer photographs of property damages and more photographs that contained humanizing elements and documented public protests. Somewhat curiously, Egin's editorial approach coincided with that of the other newspapers on this particular aspect of reporting on ETA violence carried out in the wake of the Blanco murder.

\section{References}

AA.VV. (2000). Medios de Comunicación y Procesos de Paz. Leioa: UPV/EHU

Díaz Cerveró, E. (2012). La información sobre el terrorismo de ETA como comunicación política. La perspectiva del diario francés Le Monde. In Berrocal, S. y Campos, E. (coord.). La investigación en periodismo político en el entorno de los nuevos medios. Madrid: SEP, pp. 187-203.

Entman, R. (1993). Framing: Toward clarification of a fractured paradigm. In Journal of Communication, vol. 43, $\mathrm{n}^{0} 3,51-58$.

Espada, A. (2002). Diarios. El tratamiento periodístico del terrorismo, in El Correo-Aula de Cultura Virtual. In: http://servicios.elcorreo.com/auladecultura/ arcadiespada3.html (last accessed Mar 22, 2013).

Esparza, R. y Parejo, N. (2012). Getting Closer: Photography, Death, and Terrorist Violence in the Basque Country. In: Mingolarra, J.A., Arocena, C. y Martín, R. (eds.) Violence and Communication. Reno: University of Nevada, 129-144.

Gimenez Armentia, P. (2006). Una nueva visión del proceso comunicativo: la teoría del enfoque (framing). In: Comunicación y hombre, $\mathrm{n}^{0}$ 2, 55-66. 
Idoyaga, P. and Ramírez de la Piscina, Tx. (2000). Política informativa de El País y ABC ante la nueva situación política del País Vasco (1998-2000). In: Zer. Revista de Estudios de Comunicación, $\mathrm{n}^{0}$ 10, 257-279.

Igartua Perosanz, J.J. et al. (2007). Un análisis de contenido desde la teoría del framing. In: Estudios sobre el Mensaje Periodístico, no ${ }^{0} 13,91-110$.

Kepplinger, H.M. and Habermeier, J. (1995). The impact of Key Events on the Representation of Reality. In: European Journal of Communication, vol. 10, $\mathrm{n}^{\mathrm{o}}$ 3, 271-390.

Lucas Marín, A., García Galera, C. and Ruíz San Román, J.A. (1999). Sociología de la comunicación. Madrid: Trotta.

Messaris, P.; Abraham, L. (2001). The role of images in framing news stories. In Reese, S.D.; Gandy, O.H.; Grant, A.E. (eds.). En: Framing public life. Perspectives on media and our understanding of the social world. Mahwah, NJ: Lawrence Erlbaum Associates, 215-226.

Parejo Jiménez, N. (2004). Fotografía y muerte: Representación gráfica de los atentados de ETA (1968-1997). Leioa: Servicio Editorial de la UPV/EHU.

Piñuel, J.L. and Gaitán, J.A. (1995). Metodología general: conocimiento científico e investigación en la comunicación social. Madrid: Síntesis.

Sánchez Duarte, J.M. and Sampedro, V. (2011). Visibilidad mediática y terrorismo: El caso de las víctimas de ETA. In: Textual \& Visual Media, nº 4, 183-210.

Tankard, J. al. (1991). Media frames: approaches to conceptualization and measurement. Paper presented to the annual meeting of the Association for Education in Journalism and Mass Media, Boston, MA, August, 1991, 7-10.

Vicente Mariño, Miguel and López Radabán, Pablo (2009). Resultados de la investigación sobre framing: sólido avance internacional y arranque de la especialidad en España. In: ZER. Revista de Estudios de Comunicación, vol. 26, $\mathrm{n}^{\mathrm{o}}$ $14,12-34$.

\section{Referencia de este artículo}

Caminos Marcet, José María, Armentia Vizuete, José Ignacio y Marín Murillo, Flora (2013). The assassination of Miguel Ángel Blanco: a key event that marked the turning point in press coverage of ETA violence. En: adComunica. Revista Científica de Estrategias, Tendencias e Innovación en Comunicación, $\mathrm{n}^{\circ}$ 6. Castellón: Asociación para el Desarrollo de la Comunicación adComunica, Universidad Complutense de Madrid y Universitat Jaume I, 115-137. DOI: http://dx.doi.org/10.6035/2174-0992.2013.6.8 